\title{
INTERNATIONAL FOOD COMMODITY PRICES AND MISSING (DIS)INFLATION IN THE EURO AREA
}

\author{
Gert Peersman*
}

Abstract-Exogenous shifts in international food commodity prices, which are identified using an SVAR model with global harvest shocks as an external instrument, explain almost $30 \%$ of euro-area inflation volatility over the medium term and contributed significantly to the twin puzzle of missing (dis)inflation in the era after the Great Recession. International food price shocks have an impact on food retail prices through the food production chain, but also trigger indirect inflationary effects via a depreciation of the euro and, most important, rising wages. Finally, due to asymmetric wage responses, the inflationary effects are very different across member states.

\section{Introduction}

G LOBAL food commodity markets are characterized by substantial price swings. For example, the standard deviation of quarterly changes in international food commodity prices since the start of the millennium has been $6.0 \%$. Notwithstanding this considerable volatility, little is known about the causal effects of fluctuations in international food prices on inflation dynamics in the euro area and other advanced economies. This is surprising since food commodities are a critical input factor in the production function of the food-processing sector, while food-related items account for more than $20 \%$ of the euro-area Harmonised Index of Consumer Prices (HICP). Moreover, several studies have found that households weigh food prices much higher than its share in expenditures when forming inflation expectations, which, in turn, is a key driver of inflation dynamics in any forwardlooking macroeconomic model with sticky prices (Smets \& Wouters, 2007). ${ }^{1}$

Swings in international food prices could also have contributed to the so-called twin puzzle of euro-area inflation developments in the era after the Great Recession; that is, inflation was expected to be much lower in the period 2009 to 2012 as a consequence of the downturn, while inflation was expected to be higher in the recovery from 2013 onward (Constancio, 2015). Popular explanations for the apparent

Received for publication December 12, 2018. Revision accepted for publication April 20, 2020. Editor: Olivier Coibion.

*Peersman: Ghent University.

I thank three anonymous referees, Hilde Bjørnland, Natalie Chen, Olivier Coibion (editor), Selien De Schryder, Rob Vigfusson, participants at the National Bank of Belgium 2018 Conference on "Understanding Inflation Dynamics," the European Central Bank 2019 Conference on "Inflation in a Changing Economic Environment," the third CEBRA Workshop on "Commodities and Macroeconomics," the 2020 Applied Macro Workshop of the University of Warwick, as well as seminar participants at Ghent University, the Central Bank of Ireland and the European Commission for useful comments.

A supplemental appendix is available online at https://doi.org/10.1162/ rest_a_00939.

${ }^{1}$ According to a survey of the Norges Bank, $61 \%$ of households consider the "prices of food and non-alcoholic drinks" as the factor that influences their inflation expectations most, compared to, say, $12 \%$ "overall prices" and 3\% "gasoline prices" (Larsson, 2015). Trehan (2011) and Murphy and Rohde (2018) find that US households are more sensitive to food prices in forming inflation expectations than the share of food in the CPI. disconnect between inflation and real activity during these periods are a decline in the slope of the Phillips curve (Ball \& Mazumder, 2011) and a de-anchoring of inflation expectations (e.g., Coibion \& Gorodnichenko, 2015). However, as can be observed in figure 1, international food commodity prices rose by $40 \%$ between 2009 and 2012. A major reason for the surge in food prices was a substantial decline in global harvest volumes due to serious droughts around the world in the summers of 2010 and 2012 (De Winne \& Peersman, 2016). In the subsequent years, a period of excellent harvest conditions, food commodity prices collapsed by $30 \%$. The concurrent evolution of international food prices and euroarea headline inflation in this era is remarkable. Given the importance of food-related items in the HICP, developments in global food markets could thus have contributed to the twin puzzle.

Another observation is that policymakers and researchers consider fluctuations in food commodity prices often only in tandem with other commodities or crude oil prices. Specifically, food and other commodities are typically aggregated into a broad commodity price index to analyze the impact on inflation developments. The reasoning is that the prices of commodities are jointly determined by the global business cycle. This interpretation is, however, not unequivocal. In contrast to industrial commodities, which are primarily affected by input demands, along with crude oil, food commodities are also subject to major independent supply disruptions (Blomberg \& Harris, 1995). Hence, it is important to examine shifts in food commodity prices as an independent driver of inflation.

Several empirical studies from policy institutions have explored the link between food commodity prices and inflation (Blomberg \& Harris, 1995; Furlong \& Ingenito, 1996; Vavra \& Goodwin, 2005; Pedersen, 2011; Ferrucci, JimenezRodriguez, \& Onorante, 2012; Furceri et al., 2015). However, a caveat of these studies is that they are all based on reduced-form time series models that only explore unconditional comovement in the data and cannot establish causal links. The analysis in these studies is based on a so-called pricing chain approach, which assumes that food commodity price innovations can contemporaneously affect retail prices, but the opposite takes time. More precisely, all (reducedform) food commodity price innovations are considered as shocks that are transmitted along the supply chain from producer to wholesale and to retail levels. The point in question is that this approach is not well defined because changes in food commodity prices could be triggered by both supply and demand shocks. For example, the first signs of an aggregate demand shock might be visible in flexible commodity markets and affect final consumer prices with a delay due to price 
Figure 1.-Fluctuations in International Food Commodity Prices and Euro-Area HiCP Inflation

— International food commodity prices (USD, pps) - left axis

-- HICP inflation (yoy) - right axis

100

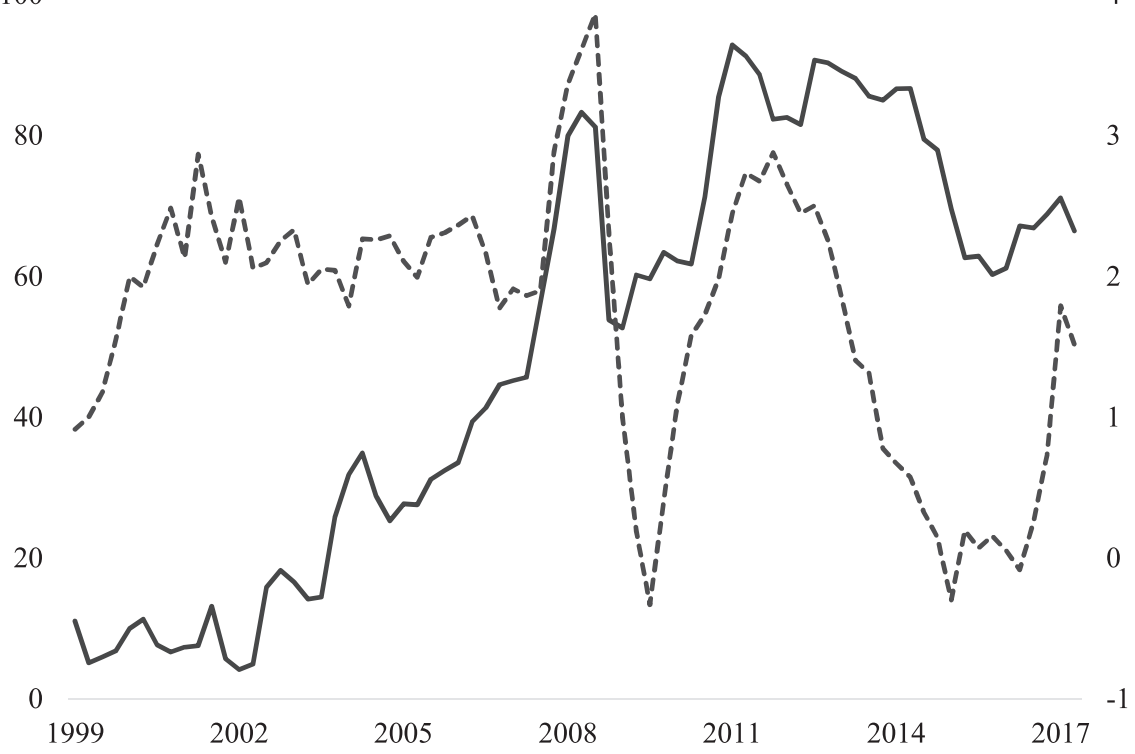

The international food commodity price index is a trade-weighted average of prices for cereals, vegetable oils, meat, seafood, sugar, bananas, and oranges. The figures show 100 times the natural log of the index. HICP inflation is year-on-year growth rate of the HICP.

Sources: IMF and ECB.

stickiness in final good markets. Such estimates can at best be informative about the signaling role of food prices for future inflation, but they cannot be given a causal interpretation. If one is interested in a causal interpretation and a better understanding of the pass-through, it is crucial to isolate changes in food commodity prices that are strictly exogenous and not endogenous responses to other macroeconomic shocks.

In this paper, I estimate the causal effects of fluctuations in international food prices on euro-area inflation dynamics using a structural vector autoregressive model in which international food commodity price shocks are identified with an external instrument, that is, an SVAR-IV or proxy SVAR in the spirit of Stock and Watson (2012) and Mertens and Ravn (2013). Elaborating on De Winne and Peersman (2016), I first construct a quarterly series of unanticipated harvest shocks of the world's four most important staple food commodities (corn, wheat, rice, and soybeans) that occurred outside Europe and were unrelated to global economic developments. In a second step, the harvest shocks are used as an instrument to identify exogenous international food commodity price shocks within the VAR model.

The estimates reveal that international food commodity price shocks are very important for euro-area inflation dynamics, explaining almost $30 \%$ of the forecast error variance of the HICP in the medium term. This is roughly six times the share of food commodities in household expenditures. A $1 \%$ rise in international food commodity prices augments the HICP by $0.08 \%$ after eight quarters. In addition, disturbances in international food markets contributed significantly to both the missing disinflation and missing inflation periods after the Great Recession. Counterfactual simulations show that euro-area inflation would have been $0.2 \%$ to $0.8 \%$ lower in the period 2009 to 2012 and $0.4 \%$ to $0.8 \%$ higher in 2014 to 2015 without the food commodity market shocks that occurred during this era.

A closer inspection of the pass-through shows that shifts in international food prices quickly spill over to EU farmgate and internal food commodity prices, and ultimately food retail prices. However, the pass-through is less than proportional and can explain only one-fourth of the inflationary effects. Specifically, international food commodity price shocks also raise inflation indirectly via a depreciation of the euro, which augments import prices of nonfood items in the HICP (including energy). In addition, the rise of food prices triggers second-round effects-that is, mutually reinforcing feedback effects between wages and prices, which amplify the impact on consumer prices. The rise in labor costs, which is even partly buffered by a fall in profits per unit output, is the most important transmission channel.

Finally, the effects are considerably different across euroarea member states. For example, the rise in German consumer prices is less than half of the area-wide effects, whereas the impact on consumer prices is significantly stronger in France, Italy, Belgium, and Luxembourg. The main reason for the cross-country differences is again the response of wages to food price increases. In particular, in member states where wages do not increase significantly, the inflationary consequences are modest, while countries that experience a substantial increase of labor costs are characterized by strong inflationary effects. These differences clearly complicate a 
single monetary policy stance in the euro area and suggest that one size does not fit all for food commodity price shocks.

This paper is related to various other studies. First, several studies have stressed the importance of global factors for domestic inflation developments (Borio \& Filardo, 2007; Ciccarelli \& Mojon, 2010; Mumtaz \& Surico, 2012; Eickmeier \& Pijnenburg, 2013). My results are consistent with this conclusion and suggest that global food commodity price shocks may be a key driver of such a relationship. Furthermore, several studies have analyzed the reasons for the missing disinflation in the postcrisis episode (Ball \& Mazumder, 2011; Gordon, 2013; Coibion \& Gorodnichenko, 2015), the missing inflation in the euro area since 2013 (Ciccarelli \& Osbat, 2017; Conti, Neri, \& Nobili, 2017), or both puzzles simultaneously (Friedrich, 2016; Bobeica \& Jarocinski, 2017). Although some of these studies find an impact of external shocks or global drivers of inflation (e.g., Bobeica \& Jarocinski, 2017), none of the existing studies explicitly examine the influence of food commodity market shocks, which turns out to be an important source of the puzzles. Finally, the presence of asymmetric effects of food price shocks across euro-area countries lies at the heart of the optimum currency area literature, which postulates that similar movements of the business cycle and symmetric shocks are crucial for a common monetary policy stance to be acceptable for all member states (Bayoumi \& Eichengreen, 1992). Overall, we can conclude that fluctuations in international food commodity prices are very relevant for euro-area inflation dynamics.

Section II describes the benchmark SVAR-IV model for the euro area and the construction of a series of unanticipated harvest shocks that is used to identify exogenous international food commodity price shocks. The baseline estimation results are reported in section III, as well as the contribution of the shocks to the missing (dis)inflation puzzle in the aftermath of the crisis. Section IV examines the transmission mechanism in more detail, while section $\mathrm{V}$ investigates differences across member states. Finally, section VI concludes.

\section{Methodology}

A large literature has used VAR models to estimate the effects of structural shocks on the macroeconomy. Such models represent the relationships between a set of macroeconomic variables within a linear system and allows the researcher to measure the dynamic effects of exogenous shocks on all the variables included in the system. The key challenge is the identification of shocks that have a structural interpretation, which requires restrictions that have to be imposed on the system. In this regard, following Stock and Watson (2012) and Mertens and Ravn (2013), an increasing number of studies use external instruments that represent an exogenous component of the target shocks to achieve identification. This SVAR-IV approach is also the methodology that I use in this paper. Section IIA discusses the baseline SVAR-IV model, while section IIB describes the external instrument that will be used to identify exogenous shocks to international food commodity prices.

\section{A. SVAR-IV Model for the Euro-Area Economy}

I assume that the euro-area economy can be described by the following reduced-form linear VAR system, ${ }^{2}$

$$
Y_{t}=\alpha+A(L) Y_{t}+u_{t},
$$

where $Y_{t}$ is a vector of endogenous variables, $\alpha$ is a matrix of constants and linear time trends, $A(L)$ is a polynomial in the lag operator $L$, and $u_{t}$ represents a vector of reducedform residuals that are related to a set of structural shocks as follows:

$$
u_{t}=B \varepsilon_{t} .
$$

$B$ is a nonsingular (invertible) matrix. The vector of endogenous variables $Y_{t}$ contains eight international and euro-area variables. For the benchmark estimations, I include international nominal (USD) food commodity prices, nominal (USD) crude oil prices, the OECD Composite Leading Indicator (CLI), the euro/USD bilateral exchange rate, real GDP, real personal consumption, the short-term nominal interest rate, and the HICP. The data are expressed in (100 times) natural logarithms and seasonally adjusted, except the interest rate, which is expressed in percentage.

Euro-area data and the exchange rate are collected from the ECB's Area-Wide Model data set. For global food commodity prices, I use the broad price index of the IMF. The index is a trade-weighted average of different benchmark food prices in USD for cereals, vegetable oils, meat, seafood, sugar, bananas, and oranges. For more details, I refer to the supplementary appendix of this paper. Besides real GDP, the benchmark VAR includes the OECD CLI and personal consumption. The CLI should capture fluctuations in (expected) global economic activity, while personal consumption is most closely related to the HICP. Crude oil prices can also be considered as a measure of (expected) economic activity, as well as an important input factor to produce food commodities. In section IIIC, I discuss the sensitivity of the results with respect to the variables included in the VAR system.

A structural analysis requires the identification of the coefficients of $B$. Because I am only interested in the effects of exogenous food commodity price shocks, and international food commodity prices are included as the first variable in $Y_{t}$, only the coefficients of the first column of $B$ have to be identified. In the existing studies that investigate the effects of food price shocks (Blomberg \& Harris, 1995; Pedersen, 2011; Ferrucci et al., 2012), this is typically done by assuming that $B$ is a lower triangular matrix (i.e., a Cholesky decomposition

\footnotetext{
${ }^{2}$ Ferrucci et al. (2012) argue that the pass-through of food commodity price shocks may be nonlinear and depend on the sign and size of the shock. Although this may indeed be the case, the analysis of nonlinearities is, however, out of the scope of this paper.
} 
THE REVIEW OF ECONOMICS AND STATISTICS

of the variance-covariance matrix of the reduced-form residuals). The implicit assumption is that shifts in international food commodity prices can have an immediate impact on all other variables in the system, but not the other way around for other shocks. For structural analysis, this assumption is not reasonable since food commodities are traded in highly competitive and flexible markets. The shocks that are identified this way are in essence a combination of exogenous food price shocks and endogenous responses to other structural shocks. At best, such results can be informative about the signaling role of changes in food prices for future inflation but are not instructive about causal effects.

To identify shifts in international food commodity prices that are strictly exogenous, in this paper I follow an approach that has been proposed by Stock and Watson (2012) and Mertens and Ravn (2013). Both studies show how structural shocks can be identified with an external instrument. Specifically, an external instrumental variable $Z_{t}$ can be used to estimate the coefficients of the first column of $B$ if the following conditions are satisfied:

$$
\begin{aligned}
& E\left[Z_{t} \varepsilon_{t}^{\varepsilon^{\prime}}\right] \neq 0, \\
& E\left[Z_{t} \varepsilon_{t}^{2^{\prime}}\right]=0,
\end{aligned}
$$

where $\varepsilon_{t}^{1}$ is an exogenous food commodity price shock and $\varepsilon_{t}^{2}$ a vector of all other structural shocks affecting the economy. Equations (3) and (4) postulate that the external instrumental variable should be correlated with exogenous food commodity price shocks and uncorrelated with all other structural shocks. These requirements correspond to the so-called instrument relevance and exogeneity condition, respectively. Notice that the instrumental variable is not the full shock series, but rather captures an exogenous component of the shock, which is typically measured with error. In this regard, Mertens and Ravn (2013) call such an instrument a noisy measure of the true shocks. For more details and implementation, I refer to Stock and Watson (2012) and Mertens and Ravn (2013). Below, I propose an instrument that can be used for the identification of exogenous food price shocks.

\section{B. Unanticipated Harvest Shocks}

I elaborate on De Winne and Peersman (2016) to construct an instrumental variable that should have a meaningful effect on food commodity prices and is plausibly uncorrelated with other macroeconomic shocks. Although food prices can immediately respond to macroeconomic shocks, the construction of the instrument explores the fact that this is not the case for the production of cereal commodities because there is a time lag of at least one quarter (i.e., three to ten months) between the decision to produce (planting) and actual production (harvest) of cereal commodities. Put differently, at the quarterly frequency, harvest volumes cannot contemporane- ously be affected by changes in macroeconomic conditions. At the same time, harvest volumes are subject to shocks that are exogenous to the economy, such as changing weather conditions or crop diseases. ${ }^{3}$

More specifically, De Winne and Peersman (2016) construct a quarterly global food production index that aggregates the harvests of the four major staple food: corn, wheat, rice, and soybeans. These four food commodities are storable and traded in integrated global markets and characterize developments in global food markets reasonably well. ${ }^{4}$ To do this, annual harvest volumes of 192 countries are combined with these country's planting and harvesting calendars for each of the four crops in order to assign the harvest volumes to a specific quarter. The harvests are then aggregated across crops and countries using calorie weights to obtain a proxy for global food production. In a next step, De Winne and Peersman (2016) embed the composite food production index in a VAR model that also includes global food commodity market and US macroeconomic variables, and identify shocks to the production index using a Cholesky decomposition with the production index ordered first. Due to the time lag of at least one quarter between the planting season and the harvest of the crops, the shocks to the production index are exogenous with respect to the macroeconomy. It turns out that a fall in the production index raises food commodity prices and depresses economic activity in the United States.

In this paper, I use the same procedure to construct a composite global food production index. However, in contrast to De Winne and Peersman (2016), I do not include the harvests of European countries in the index. The reason is that disruptions in European harvests could, for example, be caused by weather shocks that simultaneously affect European harvest volumes, agricultural production, and economic activity. The presence of possible direct effects of weather shocks on the euro-area economy (beyond changes in food commodity prices) could distort the estimations. For the same reason, in the estimations below, I orthogonalize the food production index to global weather phenomena that may simultaneously affect European and non-European harvests.

\footnotetext{
${ }^{3}$ It is realistic to assume that a possible influence of farmers on the volumes during the harvesting quarter is meager relative to variation induced by weather conditions or diseases affecting crops. For example, since in-season fertilization strategies are inefficient and often even counterproductive for the four staple food items - fertilization should be implemented before or shortly after planting - it is not realistic that farmers increase food production significantly by raising fertilization activity during the harvesting quarter. On the other hand, farmers could always destroy crops or treat diseases insufficiently in response to declining economic activity, but that is not likely to happen at a global scale. For more details and evidence supporting this assumption, I refer to De Winne and Peersman (2016).

${ }^{4}$ Together, they account for approximately $75 \%$ of the caloric content of food production worldwide and represent approximately one-third of the broad food commodity price index. The prices of other crops are also typically strongly related to these four staple food items because they are possible substitutes and affected by the same weather conditions (Roberts \& Schlenker, 2013). Furthermore, the prices of animal commodities and dairy products usually move in parallel because a large fraction of cereal commodities are used to sustain animals, which affects the production costs of animals and dairy products. One calorie of meat, for example, requires more than one calorie of feed stock.
} 
Furthermore, in contrast to De Winne and Peersman (2016), I do not include the production index directly into the VAR model, but use it to construct an external instrument for the identification of exogenous international food commodity price shocks. There are several reasons for this choice. First, innovations to the food production index are conceptually a noisy measure of food production shocks rather than the full shock series. For example, De Winne and Peersman (2016) managed to assign only two-thirds of annual global food production to a specific quarter, while the allocation procedure encompasses measurement errors. ${ }^{5}$ It is thus more appropriate to consider the innovations as an instrumental variable. Second, the innovations to the index only capture food production shocks during the harvesting quarter. In particular, anticipated food production shocks (e.g., due to weather conditions before the start of the harvesting season) may already be reflected in food commodity prices before the start of the quarter. In addition, the index does not capture shocks to other (noncereal) segments of global food commodity markets. Put differently, the production shocks represent only a confined subset of all exogenous food price disturbances, which would imply a serious underestimation of the relevance for inflation developments and the contribution to the missing (dis)inflation in the euro area. Finally, the SVAR-IV approach allows for more flexibility. For example, the sample period, variables, and number of lags for the construction of the instrumental variable can be different from the VAR model.

To obtain the instrumental variable series, I estimate the following harvest equation,

$$
q_{t}=\beta_{0}+\beta_{1} t+\beta_{2} \Psi_{t}+B_{1}(L) X_{t}+B_{2}(L) q_{t}+\xi_{t},
$$

where $q_{t}$ is the natural logarithm of the quarterly global food production index excluding European harvests. The index is seasonally adjusted using the Census X-13 ARIMA-SEATS Seasonal Adjustment Program (method X-11). $t$ is a linear time trend. $\Psi_{t}$ is a vector of the Multivariate ENSO Index (MEI), the Oceanic Niño Index (ONI), and a dummy variable based on the US National Oceanic and Atmospheric Administration (NOAA) definition of El Niños, which should control for global weather phenomena that may simultaneously affect European and non-European harvests. $X_{t}$ is a vector of control variables that could have a lagged (after one quarter) influence on global food production: the corresponding real food commodity price index (weighted av-

\footnotetext{
${ }^{5}$ For several crops of individual countries, it is not possible to assign the annual harvest volumes to a specific quarter because there is more than one harvesting period within a calendar year or an overlap of the planting and harvesting seasons at the quarterly frequency. Overall, the index covers $84 \%$ of global corn production, $16 \%$ of rice production, $96 \%$ of soybean production, and $82 \%$ of wheat production. Notice also that whenever a single harvesting season is spread over two subsequent quarters, the production volume is allocated to the first quarter, which might imply measurement errors. See De Winne and Peersman (2016) for a detailed discussion of the harvest data.
}

erage of corn, wheat, rice and soybeans), the real price of other food commodities (broad food commodity price index that also includes, for example, meat, seafood, and fruit), the real price and global production volume of crude oil (used in the production, processing and distribution of food commodities), an index of global economic activity (worldwide industrial production), the OECD CLI, and the MSCI world equity price index (to measure expected economic activity). ${ }^{6}$ $B_{1}(L)$ and $B_{2}(L)$ are polynomials in the lag operator, with $L=6$. Equation (5) is estimated over the period 1961Q1 to 2016Q4, the longest sample available for all series. If we assume that the information set of local farmers is not greater than equation (5), the residuals $\xi_{t}$ can be considered as a series of unanticipated harvest shocks that can be used as an external instrument to identify exogenous international food commodity price shocks, as described in section IIA. As shown in figure A1 of the supplementary appendix, the variability of harvest volumes and magnitude of the shocks has been substantial in the sample. Specifically, the standard error of changes in the production index and the shocks has been 6.5 and 4.1 percentage points, respectively.

\section{Benchmark Estimation Results}

Since the most recent Area-Wide Model data set covers the period 1970 to 2016, I estimate the benchmark SVAR-IV model over the sample period 1970Q1 to 2016Q4 with four lags. To allow for possible cointegration relationships between the variables, the VAR is estimated in levels (Sims, Stock, \& Watson, 1990). I use the unanticipated harvest shocks as an external instrument to identify the first column of $B$. As argued in section IIB, these shocks are plausibly uncorrelated with other macroeconomic shocks, which fulfills the exogeneity condition postulated in equation (4). In addition, the first-stage $F$-statistic and robust $F$-statistic of the instrument turn out to be 23.9 and 26.1, respectively. The harvest shocks thus also fulfill the instrument relevance condition of equation (3). ${ }^{7}$ In section IIIA, I discuss the impulse response analysis of international food commodity price shocks, while section IIIB evaluates the relevance for euro-area inflation dynamics and the contribution to the missing (dis)inflation in the period after the Great Recession. Section IIIC discusses the robustness of the results.

\footnotetext{
${ }^{6}$ Since nominal prices are expressed in USD, food commodity and crude oil prices are deflated by US consumer prices excluding food and energy to retrieve real prices. In particular, what matters for farmers are real profits (purchasing power) of increasing or decreasing their harvest volumes. Notice, however, that the results are almost identical for nominal prices.

${ }^{7}$ The $R^{2}$ of the regression of the reduced-form residual of food commodity prices on the instrumental variable is 0.12 . The reliability statistic of Mertens and Ravn (2013) is 0.17 , which corresponds to a correlation of 0.41 between the instrumental variable and the true shock of interest. Overall, these statistics indicate that the instrument contains valuable information for the identification of structural food commodity price shocks.
} 
Figure 2.-EFFects of a $1 \%$ InCREASE In InTERnational Food Commodity Prices

Food commodity prices (USD)

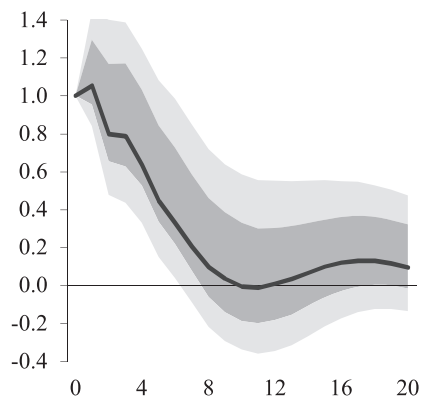

\section{Crude oil prices (USD)}

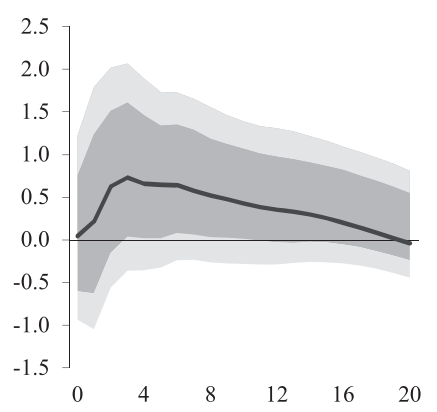

OECD CLI

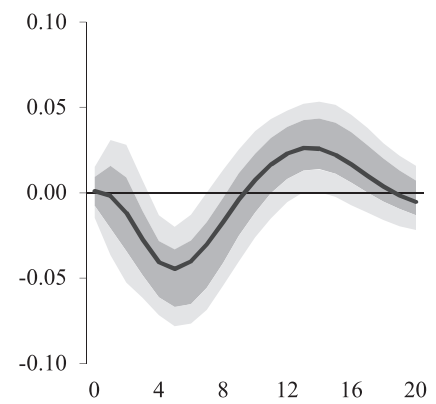

Euro-per-USD exchange rate

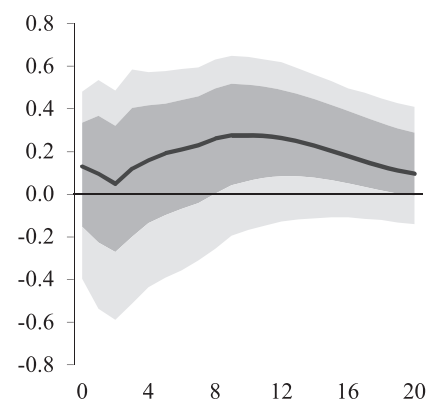

$68 \%$ and $90 \%$ confidence intervals constructed using a moving block bootstrap; horizon is quarterly.

\section{A. Impulse Response Analysis}

Figure 2 shows the impulse responses to a $1 \%$ rise in international food commodity prices on all the variables included in the VAR model, together with $68 \%$ and $90 \%$ confidence intervals. The intervals are constructed using the moving block bootstrap described in Bruggemann, Jentsch, and Trenkler (2016), based on 5,000 replications. ${ }^{8}$ The rise in food prices reaches a peak of $1.05 \%$ after one quarter, followed by a gradual decline back to the baseline after about eight quarters. The food commodity price shock leads to a temporary decline in economic activity that is statistically significant. In particular, real GDP decreases by $0.08 \%$ at its peak, which is attained after roughly eight quarters. Similarly, personal consumption decreases by $0.06 \%$ at its peak, while there is a temporary decline in the OECD CLI.

The key variable in the context of this study is the response of the euro-area HICP. The rise in international food commodity prices augments consumer prices by $0.08 \%$ after eight quarters, which is surprisingly large. This can be illustrated by simple back-of-the-envelope calculations based

\footnotetext{
${ }^{8}$ Bruggemann et al. (2016) show that the residual-based moving block bootstrap results in asymptotically valid inference, whereas wild bootstrap intervals for structural impulse responses may understate the uncertainty in finite samples. See Jentsch and Lunsford (2019) and Mertens and Ravn (2019) for a discussion of bootstrap procedures for SVAR-IV models.
}

Real GDP

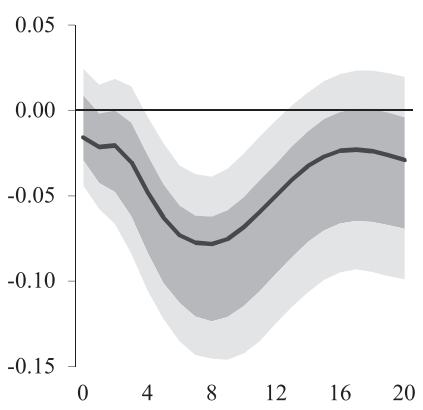

Real personal consumption
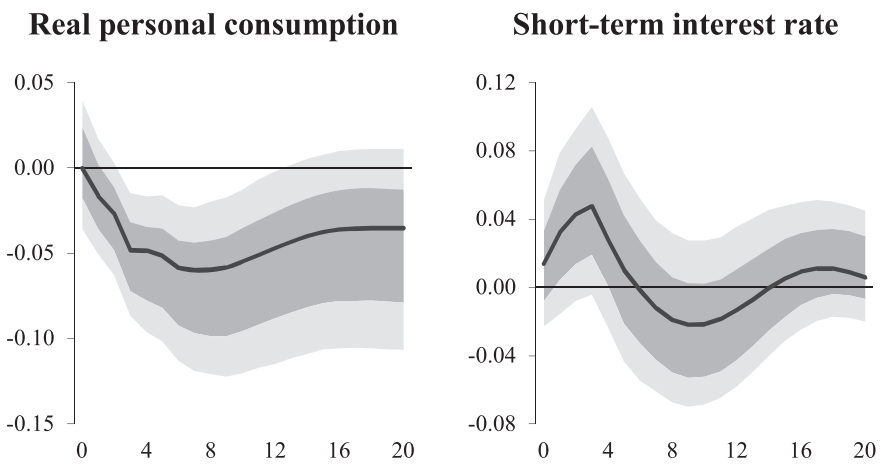

HICP

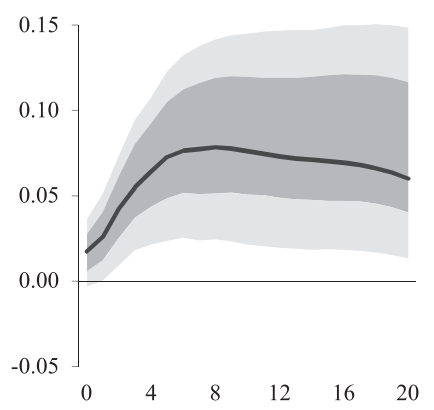

on economic accounts of the European agricultural sector. ${ }^{9}$ Specifically, the share of imported food commodities in total household expenditures is approximately $1.1 \%$, which implies that the rise of international prices can account for at most one-seventh of the HICP response. Yet the overall share of food commodities in household expenditures (net imports and EU production of food commodities) is about $4.8 \%$. In other words, even if there is full pass-through to European food commodity prices and ultimately retail prices, this can only explain about half of the inflationary effects. Furthermore, in contrast to the pattern of international food commodity prices, the impact on consumer prices is persistent. The HICP is still $0.06 \%$ higher after five years. Clearly, there should be important indirect effects of changes in international food commodity prices on the HICP.

Figure 2 shows a temporary monetary policy tightening in order to stabilize the inflationary consequences, which likely contributes to the negative output effects of the food shocks. There appears to be no shift of crude oil prices on impact. The shocks are thus unrelated to oil price innovations. There is, however, a moderate increase of oil prices at longer horizons, which could have contributed to the rise in the HICP. Even though the estimated uncertainty is quite large, another

\footnotetext{
${ }^{9}$ For the calculation of the shares of food commodities in household expenditures, I refer to the supplementary appendix. These are for the period 2005 to 2018.
} 
Figure 3.-CONTRIbution of Shocks to Forecast ERror VARIANCE DeCompositions

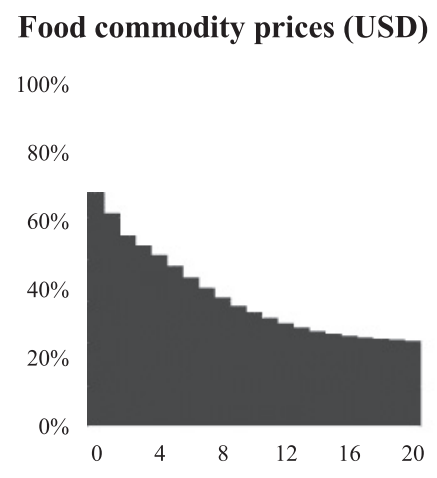

Crude oil prices (USD)

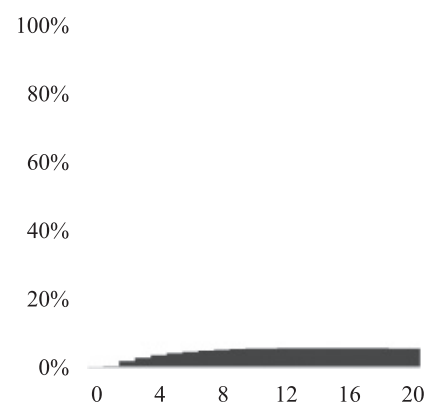

Horizon is quarterly.
OECD CLI

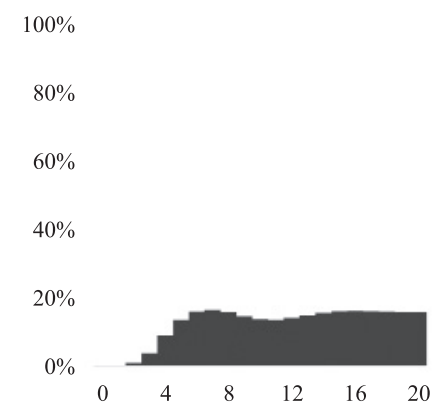

Euro-per-USD exchange rate

$100 \%$

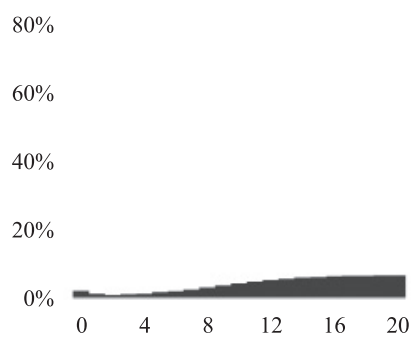

interesting observation is the depreciation of the euro in relation to the dollar triggered by the food price shock. The weakening of the euro implies that (nonfood) import prices also increase, which may partly explain the strong overall inflationary effects. In section IV, I analyze the indirect effects and the role of the oil price increase and exchange rate depreciation in more detail.

\section{B. International Food Price Shocks and Euro-Area Inflation}

Montiel et al. (2016) show how the covariances between an external instrument and the reduced-form VAR innovations can be used to estimate the contribution of the target shock to the forecast-error variance of the variables that are included in the VAR system, to identify the target structural shock series and calculate historical decompositions. The former is useful to assess the relevance of international food commodity price shocks for inflation fluctuations, while historical decompositions can be used to measure the influence on the missing (dis)inflation puzzles.

Figure 3 shows the variance decompositions of the benchmark variables. On impact, $68 \%$ of the forecast error variance of international food commodity prices is caused by exogenous food market disturbances. The contribution, however, declines to $25 \%$ in the long run. In other words, food commodity price fluctuations are predominantly endogenous responses to other shocks in the economy. Nevertheless, food commodity market shocks explain a large fraction of the fore-

Real GDP

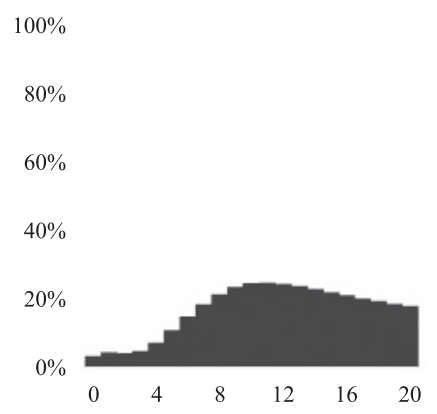

Real personal consumption

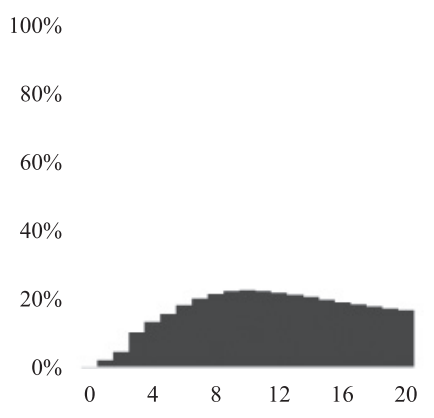

HICP

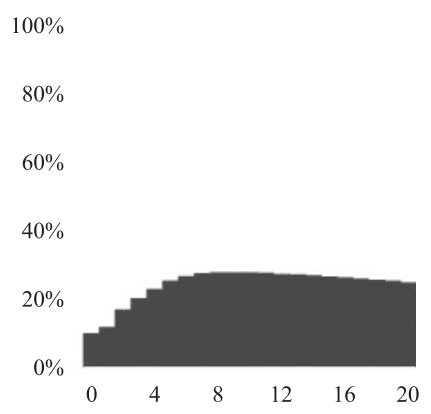

Short-term interest rate

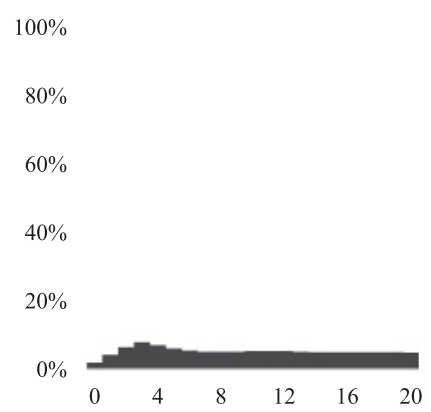

cast error variance of consumer prices in the euro area. In particular, almost $30 \%$ of HICP volatility is caused by such shocks at the two-year horizon and $25 \%$ in the long run. Again, this is considerably larger than the share of (international) food commodities in household expenditures. Developments in global food commodity markets are hence important for euro-area inflation fluctuations. The shocks further explain $17 \%$ of the forecast error variance of real GDP and personal consumption ( $24 \%$ at its peak). The contribution to the variance of the other variables is modest.

Have disruptions in global food commodity markets been relevant for inflation in the aftermath of the Great Recession? Figure 4 shows the counterfactual evolution of international food commodity prices, HICP (year-on-year) inflation and real GDP (year-on-year) growth since 2000 in the absence of food commodity price shocks. Figures for the whole sample period, together with confidence intervals, are shown in the supplementary appendix.

Some interesting observations are worth mentioning. First, the surge of international food commodity prices since the start of the millennium, a period that is described as the "global food crisis," was mainly an endogenous response to macroeconomic shocks that occurred outside food markets. In particular, the bulk of the deviation from the baseline projection - that is, the evolution of food commodity prices in the absence of all shocks implied by the VAR modelappears not to be caused by exogenous food price shocks. This finding is consistent with several studies that have 
Figure 4.-Counterfactual Evolutions in Absence of Food Commodity PRICE SHOCKS

International food commodity prices

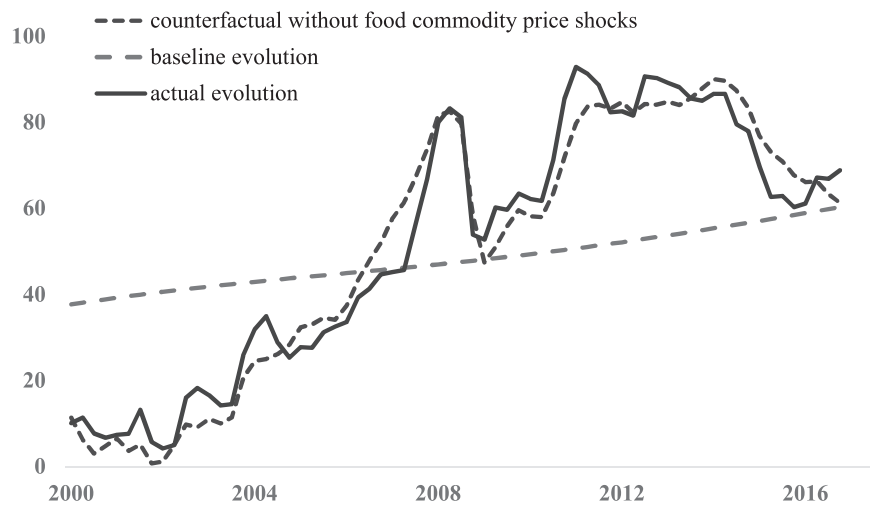

HICP (year-on-year) inflation

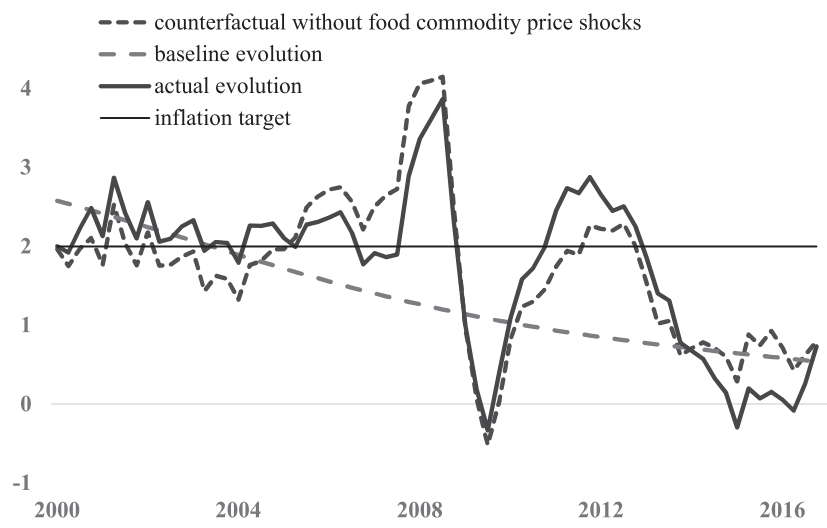

Real GDP (year-on-year) growth

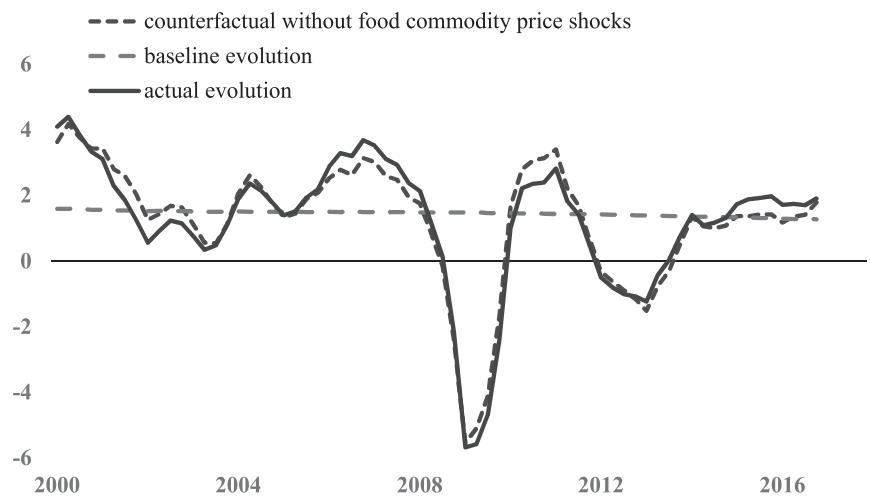

analyzed the reasons of the food crisis. For example, Abbott, Hurt, and Tyner (2011) argue that soaring oil prices, in combination with policies to encourage biofuels production, triggered a significant rise in the demand for food commodities between 2004 and 2010. Enders and Holt (2014) document that economic growth in emerging economies, low interest rates, and the depreciation of the dollar contributed to the changes in food commodity prices during this period.
The top panel of figure 4, however, reveals that exogenous food commodity market disturbances also contributed to the large swings in global food commodity prices in the era surrounding the Great Recession. Whereas the contribution was persistently negative between 2005 and 2008, a period of several upward revisions of world cereal output forecasts, unfavorable food market shocks augmented international food commodity prices by approximately $10 \%$ in 2009, almost $15 \%$ in 2010 and 2011, and again $8 \%$ in summer 2012. These hikes are consistent with severe droughts in Russia and eastern Europe in summer 2010 and in Russia, eastern Europe, Asia, and the United States in summer 2012. In contrast, international food commodity prices were nearly 10\% lower between 2014 and 2016 as a consequence of autonomous developments in food commodity markets. The latter episode has indeed been characterized by excellent harvest conditions.

The counterfactual evolution of HICP inflation shows that the events in global food markets had an important impact on inflation in the euro area. Specifically, inflation would have been between $0.2 \%$ and $0.8 \%$ lower in the period 2009 to 2012 but $0.4 \%$ to $0.8 \%$ higher in 2014 and 2015 . These magnitudes are economically meaningful. Thus, we can conclude that food commodity market shocks were partly responsible for the missing disinflation in the aftermath of the Great Recession and the missing inflation in the subsequent recovery. Interestingly, unfavorable food commodity price shocks aggravated the recession in the euro area. In particular, food market shocks reduced real GDP growth by roughly $0.7 \%$ in 2009 and 2010, yet favorable food price shocks supported the recovery in 2015 and early 2016.

\section{Sensitivity and Robustness of the Results}

In the supplementary appendix, I discuss several robustness and sensitivity checks of the baseline results. I first assess the relevance of using an external instrument to identify food commodity price shocks by comparing the results with the recursive identification strategy that is usually used in the literature. At its peak, the impact on the HICP of the shock that is identified with the external instrument turns out to be twice as large. In contrast to the benchmark results, a recursively identified food commodity price innovation is associated with an appreciation of the euro against the USD and a significant rise of oil prices on impact. The use of an external instrument hence matters for the effects.

Second, the results are not sensitive to the construction of the external instrument. For example, the impulse responses, variance decompositions, and contribution to the twin puzzle of inflation are very similar when I include European harvests in the global food production index, when I include the global economic policy uncertainty index of Baker, Bloom, and Steven (2016) and the VIX as additional control variables in equation (5), when I allow for an immediate effect of all the control variables (except food commodity prices) 
on harvest volumes, and when I use the narrative food commodity price shocks of De Winne and Peersman (2016) as an alternative or additional instrumental variable. The results are also robust for several perturbations to the VAR model, such as including additional variables (e.g., global economic policy uncertainty, world equity prices, global inflation, and nominal long-term interest rates) and the estimation of the VAR model in first differences. ${ }^{10}$

While the effects on the HICP are very similar when the harvest shocks are directly included in the VAR model (i.e., Cholesky identification with the external instrument ordered first in the VAR), the contribution of the shocks to euro-area inflation volatility is substantially lower (less than $10 \%$ ). This is consistent with the conjecture in section IIB that the harvest shocks represent only a subset of food market disturbances and confirms that it is important to use the shocks as an external instrument to measure the relevance for inflation dynamics. The sensitivity analysis also reveals that it matters to include the OECD CLI in the VAR model. More specifically, when this forward-looking variable is replaced by contemporaneous indicators of global economic activity, the decline of real GDP is more sluggish, while the inflationary effects are much stronger. In addition, food commodity price shocks explain $40 \%$ to $45 \%$ of inflation volatility over the medium term. Finally, when the VAR model is estimated over a more recent sample period (e.g., from 1990 onward), the effects on the HICP are less persistent, while the contribution to the forecast error variance of the $\mathrm{HICP}$ is much higher (even more than $60 \%$ ).

As a final check, the appendix shows results for the effects of oil price shocks that are identified with an external instrument within the same VAR model. The instrument is obtained from Kanzig (2018). The correlation between the target oil and food commodity price shocks is 0.05 , which confirms that the food shocks are unrelated to oil price innovations. The impact of a $1 \%$ rise in crude oil prices on the HICP turns out to be much smaller than a rise in international food commodity prices, $0.02 \%$ at its peak, while oil price shocks explain a lower share of HICP volatility $( \pm 20 \%$ in the medium term). Notably, oil price shocks also made a relevant contribution to the missing disinflation over 2009 to 2012, and particularly the missing inflation since 2015.

\section{Transmission Mechanism of Food Price Shocks}

An advantage of the isolation of exogenous food commodity price shocks is that it allows examining the transmission mechanism in more detail. The aim of this section is to better understand the pass-through to the HICP. To do this, I estimate the following near-VAR model for several relevant

\footnotetext{
${ }^{10}$ Food commodity price shocks trigger a rise in the Baker et al. (2016) economic policy uncertainty index, a significant fall in the MSCI world equity price index, a rise in global inflation, while nominal long-term interest rates in the euro area temporarily increase.
}

additional variables,

$$
\begin{aligned}
{\left[\begin{array}{l}
Y_{t} \\
x_{t}
\end{array}\right]=} & {\left[\begin{array}{l}
\alpha \\
c
\end{array}\right]+\left[\begin{array}{cc}
A(L) & 0 \\
C(L) & D(L)
\end{array}\right]\left[\begin{array}{l}
Y_{t} \\
x_{t}
\end{array}\right] } \\
& +\left[\begin{array}{ll}
B & 0 \\
b & 1
\end{array}\right]\left[\begin{array}{c}
\varepsilon_{t}^{Y} \\
\varepsilon_{t}^{x}
\end{array}\right],
\end{aligned}
$$

where $Y_{t}$ are the variables of the benchmark VAR model and $x_{t}$ is the additional variable of interest. For these estimations, I assume that the additional variable does not affect the benchmark variables. Accordingly, the underlying shocks and interaction among the benchmark variables are invariant to the inclusion of the additional variable, which allows for a proper comparison of the effects across the variables. ${ }^{11}$ The sources of the data and construction of some series are described in the supplementary appendix. To discuss the transmission mechanism, I distinguish between the direct effects on the HICP through the food production chain (section IVA) and indirect effects triggered by other mechanisms (section IVB).

\section{A. Effects on the HICP through the Food Production Chain}

The top row of figure 5 shows the dynamic effects of a $1 \%$ increase in international food commodity prices on the main components of the HICP: food, energy, and HICP excluding food and energy. The impact after eight quarters (when the HICP response reaches its peak) and long-run effects (after twenty quarters) are also reported in table 1 , as well as the weighted contribution of the components to the overall HICP response. There is clearly an influence of international food commodity prices on retail prices of food in the euro area through the food supply chain. Specifically, there is a significant rise of HICP-food by almost $0.10 \%$ after eight quarters, about twice as large as the impact on core inflation.

Two channels could explain this. First, food commodities that are imported become more expensive for domestic residents when international prices rise. Together with the depreciation of the euro against the USD, this increases import prices of food commodities. The presence of this channel is reflected in the stronger rise of import prices (import deflator) relative to the depreciation of the nominal effective exchange rate depicted in the second row of figure 5. However, since the share of imported food commodities in total household expenditures is only $1.1 \%$ (or 5.5\% of HICP-food), this can explain at most half of the response of HICP-food.

Second, since food commodities are traded in integrated and competitive global markets, domestic food commodity

\footnotetext{
${ }^{11}$ Additionally, the data series of domestic (EU) food commodity prices, price expectations of households, and inflation expectations of professional forecasters are available only from the 1990s onward. By estimating a block exogenous system, it is possible to estimate the parameters of the benchmark variables over the full sample period and those of the additional variables over a shorter sample period. To save degrees of freedom, I set $L=2$ in $C(L)$ and $D(L)$ for the variables that are available for only a short sample period.
} 
Figure 5.-EFfects of a $1 \%$ InCREASe in InTERnATIONAL Food Commodity Prices: Other Variables

HICP - food

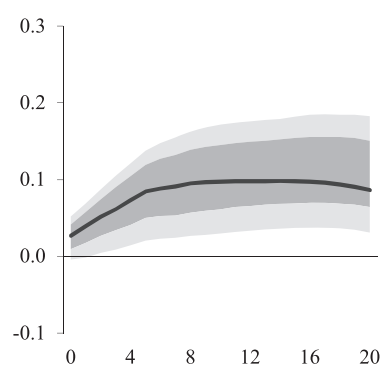

EU food commodity prices

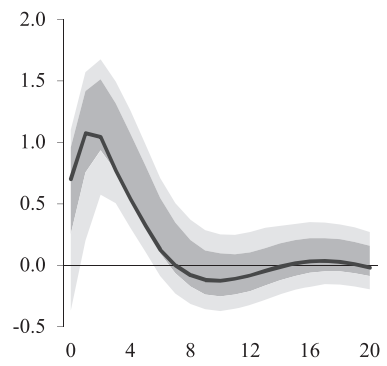

GDP deflator

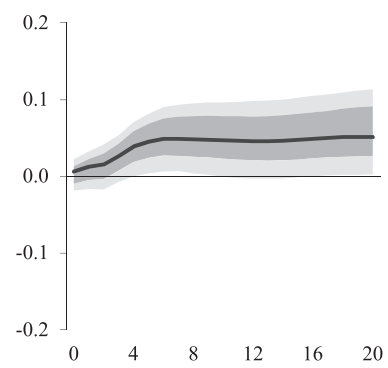

Nominal wage per head

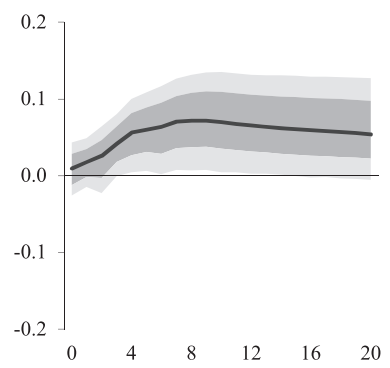

HICP - energy

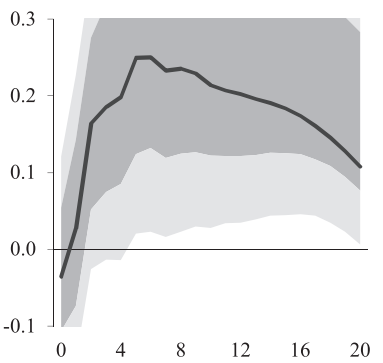

Nominal effective exchange rate

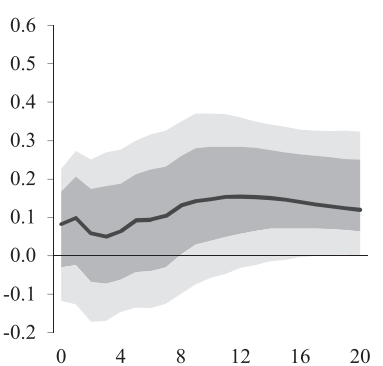

Unit labor costs

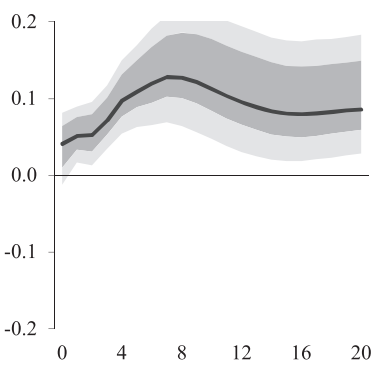

Price-wage ratio of firms

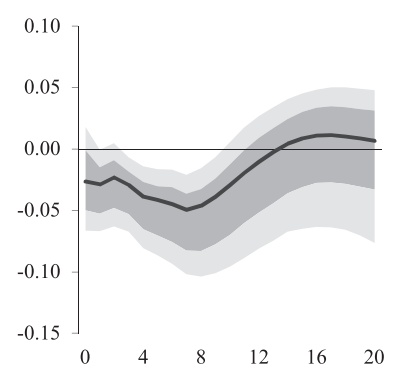

HICP - excluding energy and food

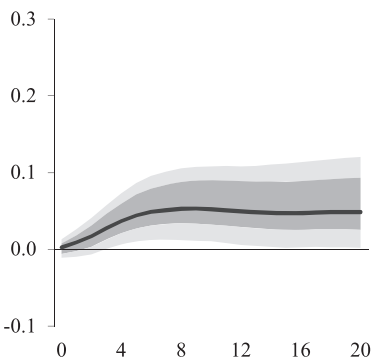

Import deflator

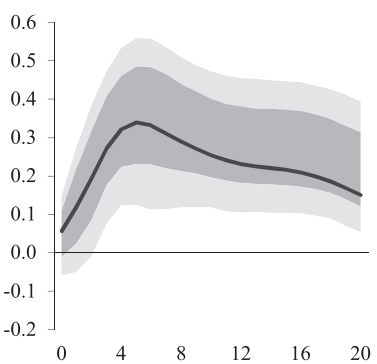

Unit profits

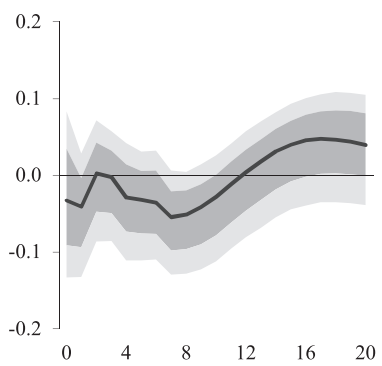

Price expectations (EC survey)

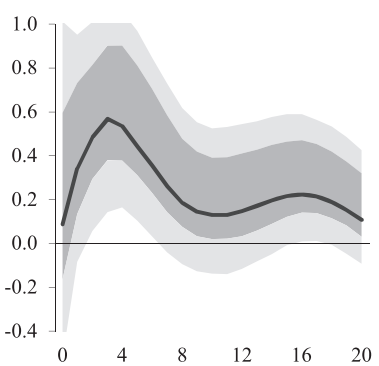

Export deflator

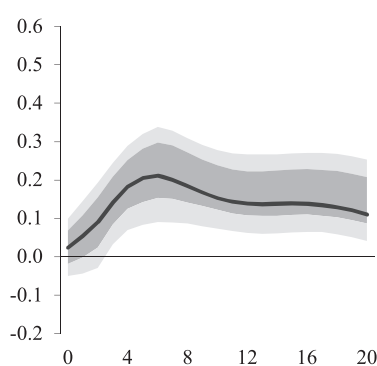

Unit taxes

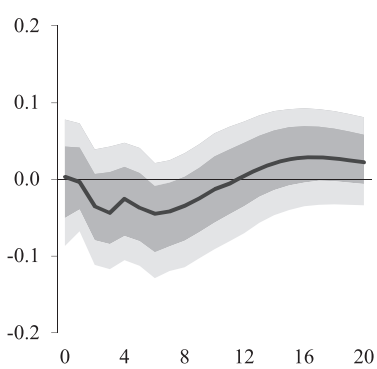

Inflation expectations (SPF)

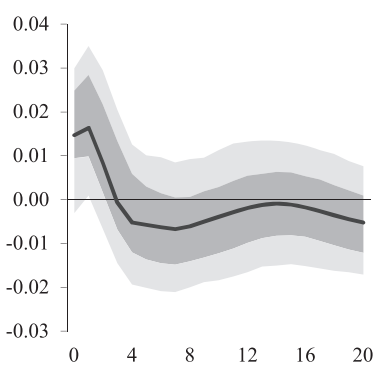

$68 \%$ and $90 \%$ confidence intervals constructed using a moving block bootstrap; horizon is quarterly.

prices could also increase when there is a rise in international prices. To assess whether this is the case, I construct a novel index of European food commodity prices, which is a weighted average of commodity prices of cereals, animals, and animal products. The indices of the product groups are, in turn, based on the price series of specific food commodi- ties. Similar to Ferrucci et al. (2012), I use the farm-gate and wholesale market prices in the European Union (EU) that are made available by DG AGRI over the period 1991 to 2017. I refer to the data appendix for more details.

As can be observed in figure 5, the pass-through of international food commodity prices to European prices is almost 
TABle 1.-DeComposition OF THE IMPaCt ON the HICP: BaCK-OF-THE-ENVELOPE CALCUlations

\begin{tabular}{|c|c|c|c|c|c|}
\hline & \multirow[b]{2}{*}{ Weight } & \multicolumn{2}{|c|}{$\begin{array}{c}\text { Impact } 1 \% \text { Rise International Food } \\
\text { Commodity Prices }\end{array}$} & \multicolumn{2}{|c|}{ Contribution to HICP Response } \\
\hline & & At Peak (8Q) & Long Run (20Q) & At Peak (8Q) & Long Run (20Q) \\
\hline \multicolumn{6}{|l|}{ Decomposition HICP response } \\
\hline HICP-Food (incl. alcohol \& tobacco) & $20.0 \%$ & 0.095 & 0.086 & 0.019 & 0.017 \\
\hline HICP-Energy & $9.5 \%$ & 0.236 & 0.108 & 0.022 & 0.010 \\
\hline HICP-Excluding food and energy & $70.5 \%$ & 0.053 & 0.048 & 0.037 & 0.034 \\
\hline \multicolumn{6}{|l|}{ Alternative decomposition } \\
\hline Import prices & $15.0 \%$ & 0.289 & 0.150 & 0.043 & 0.022 \\
\hline Domestic prices (GDP deflator) & $85.0 \%$ & 0.048 & 0.051 & 0.041 & 0.044 \\
\hline Unit labor costs & $51.8 \%$ & 0.127 & 0.086 & 0.066 & 0.044 \\
\hline Unit profits & $24.4 \%$ & -0.051 & 0.039 & -0.012 & 0.010 \\
\hline Unit taxes & $8.8 \%$ & -0.034 & 0.022 & -0.003 & 0.002 \\
\hline HICP response benchmark VAR & & 0.078 & 0.060 & 0.078 & 0.060 \\
\hline
\end{tabular}

作 not sum up to aggregate effects.

proportional. Whereas international prices increase by $1.18 \%$ at their peak (including the depreciation of the euro against the dollar), the index of domestic prices increases by $1.07 \%$. This suggests that the Common Agricultural Policy (CAP) does not isolate domestic agricultural producers from developments in global markets. ${ }^{12}$

Finally, changes in food commodity prices are only partly passed on to consumer prices. Specifically, since the share of food commodities in household expenditures is $4.8 \%$ and HICP-food represents $20 \%$ of household expenditures, a $1 \%$ rise in food commodity prices that is fully passed on to consumer prices should augment HICP-food by approximately $0.24 \%$. Since food commodity prices rise even more than $1 \%$ at their peak, while HICP-food increases by only $0.10 \%$, higher food commodity prices are partly absorbed in profit margins at various stages of the production chain and margins of retailers. Overall, as documented in table 1, the rise in HICP-food augments the HICP by $0.02 \%$ after eight and twenty quarters. Put differently, the rise in food retail prices accounts for roughly one-fourth of the peak HICP response and one-third of the response in the long run.

\section{B. Indirect Effects on the HICP}

HICP-energy and core inflation. Figure 5 and table 1 reveal a rise in energy prices by $0.24 \%$ after eight quarters, which raises the HICP by $0.02 \%$ at the peak and $0.01 \%$ in the long run. This nonnegligible impact is somewhat surprising and can be explained by two effects. The uncertainty of both effects is large (see figure 2), but the magnitudes cannot be ignored. First, there is a moderate increase of crude oil prices after a couple of quarters. In addition, there is a depreciation of the euro against the USD. Since crude oil

\footnotetext{
${ }^{12}$ The CAP consists of several measures in order to influence prices and quantities of agricultural commodities within the EU. Examples are crop subsidies for EU farmers, price support mechanisms, and tariffs on agricultural products imported from non-EU countries.
}

is usually traded in USD, while all euro-area countries are oil-importing countries, this raises HICP-energy. ${ }^{13}$

A detailed analysis of the reasons that the oil price increases and the euro depreciates is out of the scope of this paper. For example, Peersman, Rüth, and Van der Veken (2019) provide evidence that informational frictions in financialized commodity markets have resulted in spillover effects of food commodity supply shocks on oil prices since the 1990s, a finding that is consistent with the model of Sockin and Xiong (2015). A possible reason for the depreciation is the fact that the euro area has been a net importer of primary food commodities over the sample period, while the United States is a net exporter of food commodities. In addition, in the supplementary appendix, I show a more aggressive monetary policy tightening in the United States in response to food market shocks, while consumer prices rise more in the euro area in the long run. Both features are consistent with a depreciation against the dollar.

Finally, figure 5 shows that there is also a rise in the HICP excluding energy and food prices by $0.05 \%$, which is statistically significant. Given the large share in the HICP, the rise in core inflation explains roughly half of the overall response of the HICP. Again, this may (partly) be a consequence of the depreciation of the exchange rate, which raises import prices. As can be observed in figure 5 , there is indeed a depreciation of the nominal effective exchange rate, although somewhat less than the depreciation against the USD. To shed more light on this issue, I discuss an alternative decomposition of the inflationary effects.

Alternative decomposition of the effects. The rise in import prices (i.e., the sum of more expensive food, energy, and other imports) can only partly explain the overall rise of the

\footnotetext{
${ }^{13}$ In the appendix, I estimate the effects of oil price shocks within the same VAR model. When I use these effects to "switch off" the oil price increase after a food commodity price shock, the impact of food commodity price shocks on the HICP is $0.01 \%$ lower at the peak, as well as in the long run. Put differently, the contribution of the oil price increase (without the exchange rate depreciation) to the HICP response is approximately $0.01 \%$.
} 
HICP. This can be shown using an alternative decomposition of the inflationary effects, which is reported in the bottom part of table 1. More precisely, studies have shown that the import intensity of euro-area household's consumption is approximately $15 \%$ (ECB, 2010). When I apply this share to the response of the import deflator, roughly one-third of the long-run impact on the HICP can be explained by higher import prices and about half of the peak effects. Put differently, about half of the peak effects and two-thirds of the long-run inflationary effects are caused by domestic mechanisms. Indeed, when I consider the GDP deflator as representative for price pressures stemming from domestic sources, figure 5 and table 1 show that the deflator rises by $0.05 \%$, which corresponds to half the peak effects and two-thirds of the long-run response of the HICP. ${ }^{14}$

The remaining question is: Why is there such a large rise of the GDP deflator when food commodity prices increase? The answer is the existence of second-round effects, that is, mutually reinforcing feedback effects between wages and prices. Specifically, since the GDP deflator measures the price of value added per unit of output, it can be decomposed into unit labor costs, profits (gross operating surplus and mixed income) per unit of output, and net indirect taxes (taxes on production net of subsidies) per unit of output. The responses of these three components are also shown in figure 5 and table 1. As can be observed, unit labor costs increase significantly after a food commodity price shock. The magnitude is even greater than the HICP response. ${ }^{15}$ This is presumably the consequence of employees asking for higher nominal wages in the wage bargaining process to compensate for their (expected) loss in purchasing power. ${ }^{16}$ If firms pass these costs through to their selling prices, this reinforces the inflationary consequences of the food price shocks and could lead to a self-sustaining spiral of increasing wages and prices. The responses of the other components of the GDP deflator reveal that unit profits and unit taxes even temporarily decline

\footnotetext{
${ }^{14}$ Notice that imports are not only consumption goods and services, since a significant part of imports is used to produce export goods and services (which is passed on to export prices rather than euro-area consumer prices). According to ECB (2010), 5\% are direct imports for final consumption, while $10 \%$ are imports embodied in euro-area domestic produced goods and services for private consumption. This implies an overall import intensity of households' consumption of $15 \%$. The import intensities of gross capital formation and particularly extra-euro-area exports are higher, respectively, $18 \%$ and $23 \%$. On the other hand, the GDP deflator includes the rise in domestic food commodity prices. Note also that my back-of-the-envelope calculation assumes that the import intensity of $15 \%$ is representative for the shift in import prices caused by a rise in food commodity prices, which is not necessarily the case. In addition, the GDP deflator also contains exports, while the export deflator increases somewhat more than the GDP deflator (see figure 5). Hence, the exact numbers should be taken with a grain of salt. Notwithstanding these caveats, the weighted contribution of import prices $(15 \%)$ and the GDP deflator $(85 \%)$ to the HICP turns out to be quite similar to the HICP response in the benchmark VAR.

${ }^{15}$ Nominal compensation per employee increases slightly less than the HICP (see figure 5), but due to the fall in GDP, labor costs per unit of output rise more than the HICP.

${ }^{16}$ This is consistent with the response of inflation expectations collected from the ECB's survey of professional forecasters and the qualitative measure of price expectations derived from the monthly households survey of the European Commission (see figure 5).
}

to buffer the strong response of unit labor costs. Hence, employees seem to be able to transfer the temporary loss in purchasing power to producers. Overall, as documented in table 1 , the rise of wages triggers very persistent inflationary effects and appears to be the most important source of the rise in the HICP. It accounts for two-thirds of the long-run inflationary effects.

The presence of second-round effects via rising wages and persistent impact on consumer prices contrast with the evidence of De Winne and Peersman (2016) for the United States. De Winne and Peersman (2016) do not find a rise in nominal wages when food prices increase, whereas there is only a temporary rise in the GDP deflator and consumer prices. This difference in labor market dynamics is consistent with Daveri and Tabellini (1988), who find that higher labor taxes lead to higher wages in European countries, while the labor tax burden in the United States is shifted to employees. Similarly, Peersman and Van Robays (2009) document a strong rise in nominal wages in the euro area after oil supply shocks but not in the United States. A likely explanation is that employment protection is high and trade unions are very powerful in the euro area, whereas labor markets are more flexible and competitive in the United States. As discussed below, many euro-area countries also have automatic wage indexation mechanisms.

\section{The Effects across Euro-Area Member States}

It is useful to examine how consumer prices in individual euro-area countries are affected by the shocks. The resemblance of inflation fluctuations of the participating countries is, for example, a major concern for monetary policymakers in a currency union. If consumer prices react differently across member states, a single monetary policy stance may not be appropriate. For that purpose, for each of the eleven original member states, I estimate the near-VAR model described in equation (6) for some key variables. ${ }^{17}$

\section{A. Impact in Individual Countries}

Table 2 reports for each country the peak and long-run effects of international food commodity price shocks on consumer prices. The corresponding figures of the impulse responses are shown in the supplementary appendix. To assess the statistical significance of the asymmetries, figure 6 shows the differences between the individual-country and the area-wide responses, including confidence intervals. There are substantial differences across countries. For example, the

\footnotetext{
${ }^{17}$ Countries that joined more recently are not included in the analysis due to the lack of a sufficient long time series for consumer prices. In addition, these countries were not part of the fixed exchange rate regime before the launch of the euro, which could distort the estimations. Since exchange rate parities have been adjusted for several countries during the sample period, a possible distortion for the eleven original countries is also possible, which is a caveat that should be taken into account when interpreting the results. For Ireland, only data for consumer prices are available.
} 
Table 2.-Effects of a $1 \%$ Increase in International Food Commodity Prices on Member States

\begin{tabular}{|c|c|c|c|c|c|c|}
\hline & \multicolumn{2}{|c|}{ Impact on Consumer Prices } & \multirow{2}{*}{$\begin{array}{c}\text { Share Food and } \\
\text { Nonalcoholic } \\
\text { Beverages in } \\
\text { Household } \\
\text { Expenditures }\end{array}$} & \multicolumn{3}{|c|}{ Peak Effects } \\
\hline & Peak & Long Run & & Import Prices & Domestic Prices & Unit Labor Costs \\
\hline \multicolumn{7}{|l|}{ Impact individual countries } \\
\hline Belgium & 0.13 & 0.06 & $17.5 \%$ & 0.31 & 0.09 & 0.11 \\
\hline Germany & 0.03 & -0.03 & $12.5 \%$ & 0.25 & 0.01 & 0.04 \\
\hline Ireland & 0.19 & 0.15 & $15.1 \%$ & & & \\
\hline Spain & 0.12 & 0.11 & $21.3 \%$ & 0.45 & 0.08 & 0.02 \\
\hline France & 0.11 & 0.10 & $16.8 \%$ & 0.36 & 0.12 & 0.14 \\
\hline Italy & 0.11 & 0.10 & $17.5 \%$ & 0.43 & 0.10 & 0.15 \\
\hline Luxembourg & 0.11 & 0.05 & $12.1 \%$ & 0.22 & 0.17 & 0.21 \\
\hline Netherlands & 0.08 & 0.03 & $14.4 \%$ & 0.34 & 0.01 & 0.04 \\
\hline Austria & 0.07 & 0.03 & $12.7 \%$ & 0.19 & 0.02 & 0.03 \\
\hline Portugal & 0.15 & 0.15 & $20.6 \%$ & 0.26 & 0.13 & 0.18 \\
\hline Finland & 0.15 & 0.10 & $16.3 \%$ & 0.25 & 0.15 & 0.26 \\
\hline Impact euro area & 0.08 & 0.06 & $16.0 \%$ & 0.34 & 0.05 & 0.13 \\
\hline \multicolumn{7}{|l|}{ Correlations } \\
\hline Peak effect consumer prices & 1.00 & 0.88 & 0.49 & 0.18 & 0.77 & 0.69 \\
\hline LR effect consumer prices & & 1.00 & 0.72 & 0.43 & 0.64 & 0.50 \\
\hline Share food and nonalcoholic beverages & & & 1.00 & 0.64 & 0.27 & 0.10 \\
\hline Import prices & & & & 1.00 & -0.05 & -0.23 \\
\hline Domestic prices & & & & & 1.00 & 0.90 \\
\hline Unit labor costs & & & & & & 1.00 \\
\hline
\end{tabular}

Figures of the responses (including differences with euro-area response) and scatter plots of correlations can be found in the supplementary appendix. Domestic prices are effects on GDP deflator. Food shares are based on 1996-2019. Bold numbers are statistically significant (90\% confidence intervals).

impact on consumer prices in Germany is much weaker than in other countries. At its peak, the rise in German consumer prices is only $0.03 \%$, less than half of the area-wide effects. Moreover, in contrast to the area-wide effects and more in line with the pattern of international food commodity prices, consumer prices return to baseline after approximately two years. The impact on consumer prices is significantly stronger in France, Italy, Finland, Belgium, Spain, Luxembourg, and Ireland. For Austria, the Netherlands, and Portugal, the effects are not significantly different from the area-wide effects, even though the impact on consumer prices is more subdued and statistically insignificant in the long run in Austria and the Netherlands.

The cross-country differences are economically important. Relative to Germany, the peak rise of consumer prices is, for example, four to five times larger in Belgium $(0.13 \%)$ and Finland $(0.15 \%)$. Given the large contribution of food market disturbances to inflation volatility in the euro area, this clearly complicates a single monetary policy. Similar inflation fluctuations are crucial for a common policy stance to be acceptable for all member states. These findings suggest that one size does not fit all for food commodity price shocks.

\section{B. Sources of Cross-Country Differences}

The cross-country correlation between the share of food in household expenditures and the peak effects of food commodity price shocks on consumer prices is 0.49 (see table 2 ). Hence, there appears to be a relationship between the food share and the cross-country differences. However, there must also be other explanations. For example, Luxembourg has the lowest share of food consumption in household expenditures, whereas the inflationary effects are significantly larger than the area-wide effects. To investigate the sources of the differences more carefully, I estimate the effects of international food commodity price shocks on import prices, domestic prices (GDP deflator), and unit labor costs in individual countries. The results are summarized in table 2 . All figures of the impulse responses and scatter plots of the cross-country correlations that I discuss are shown in the supplementary appendix.

First, the rise in import prices cannot be the main source of the cross-country differences. In particular, the cross-country correlation between the impact on import prices and consumer prices at their peak is only 0.18 . The correlation of the effects on import prices and domestic prices is even negative $(-0.05)$. On the other hand, the correlation between the effects on consumer prices and the GDP deflator is strong (0.77). In other words, the key reason for the cross-country differences should be a domestic effect.

In line with the area-wide transmission mechanism discussed in section IV, the results reveal that second-round effects via wages are important to understand the cross-country differences. Specifically, the correlation between the peak rise in unit labor costs and the rise in consumer prices across countries is 0.69. The correlation between the effects on wages and the GDP deflator is even 0.90. At the same time, the cross-country correlation between the wage responses and impact on import prices is negative $(-0.23)$, whereas the relationship between the rise in wages and the share of food in household expenditures is negligible (0.10). This suggests 
Figure 6.-DifFerence BetweEn Individual-Country AND AREA-Wide IMPACT ON CONSUMER PRices

Germany

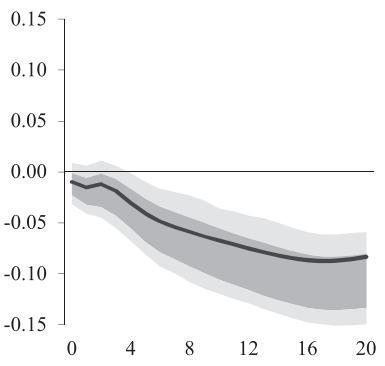

Austria

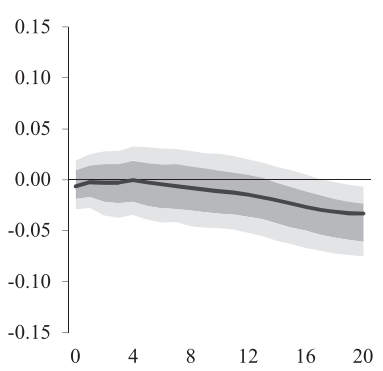

Luxembourg

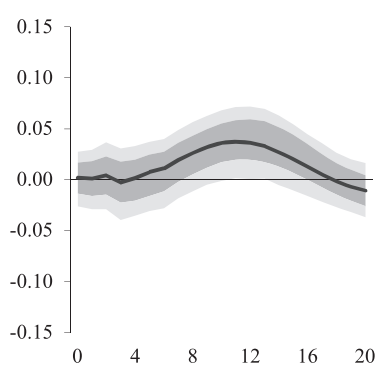

France

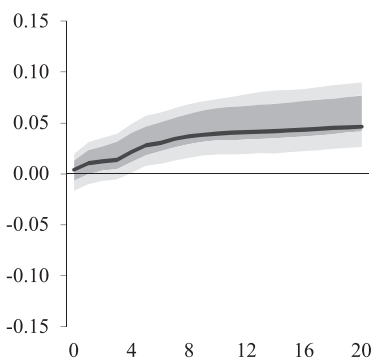

Netherlands

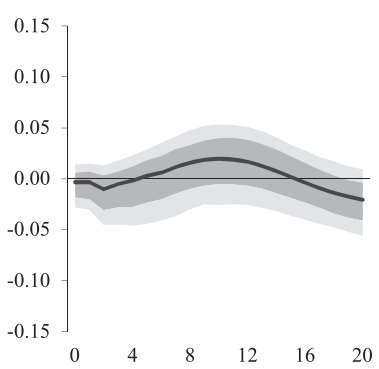

Portugal

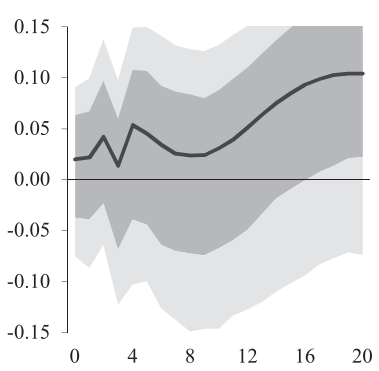

Italy

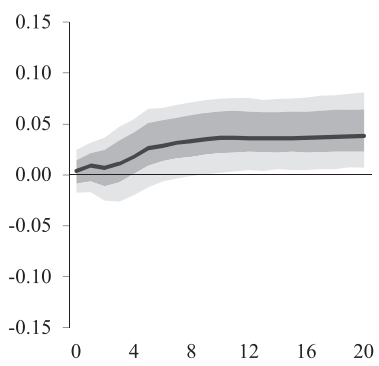

Belgium

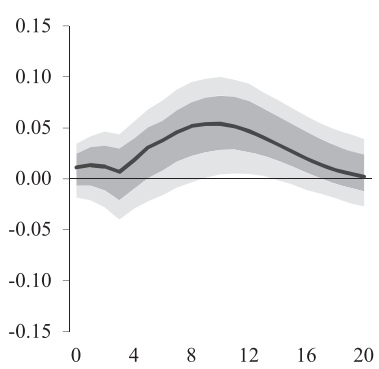

Ireland

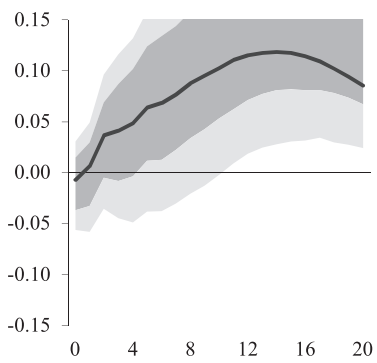

Finland

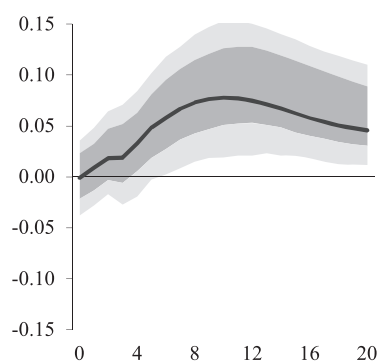

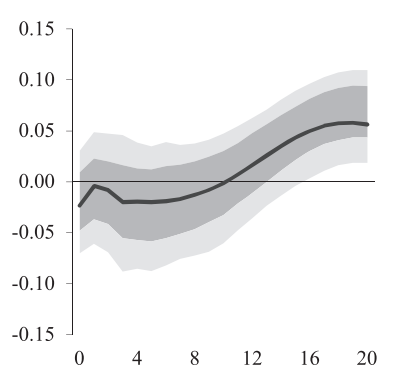

$68 \%$ and $90 \%$ confidence intervals constructed using a moving block bootstrap; horizon is quarterly.

that differences in the magnitudes of second-round effects across countries are unrelated to the food share and changes in import prices. Thus, the different degree of second-round effects across countries should predominantly be the consequence of asymmetric labor market characteristics. The same applies to the long-run effects.

It is well known that labor markets are indeed very different across euro-area member states and could be a source of asymmetric responses to macroeconomic shocks. For example, an important feature that could trigger or enhance secondround effects is the presence of automatic wage indexation mechanisms, which are clauses in contracts or laws whereby wages are to a large degree automatically linked to price developments. Such mechanisms are currently in place in, for example, Belgium, Luxembourg, Finland, and Spain (ECB, 2008). In France, minimum wages are automatically raised by inflation. Before 1993, wages in Italy were also automatically indexed to changes in the cost of living. ${ }^{18}$ Except for Spain, these are all countries that experience a substantial increase of unit labor costs after food commodity price shocks (see table 2). On the other hand, the response of unit labor costs is insignificant in countries that have no automatic indexation mechanisms, such as Germany, Austria, and the Netherlands. Portugal is the only country without formal wage indexation where wages increase considerably (though statistically not significant), but countries without formal mechanisms could still have a strong de facto indexation of wages to prices in the wage bargaining process. For example, employment

\footnotetext{
${ }^{18}$ In Spain, wage indexation is not prescribed by law, but most collective agreements include clauses specifying wage increases based on inflation. France and the Netherlands had a formal automatic cost-of-living adjustment system for all wages at the beginning of the sample, but abolished this in the early 1980s. Finally, Cyprus and Malta, which are not included in the analysis, also have systems of automatic wage indexation.
} 
protection is very high in Portugal and other southern European countries (OECD, 2013), which enhances bargaining power of employees to raise wages when they are confronted with a loss in purchasing power. For a detailed study of the influence of labor market characteristics on wage indexation, I refer to, for example, Messina and Sanz-de Galdeano (2014), who find that a rise in union coverage as well as more centralized wage bargaining increases wage indexation.

\section{Conclusion}

Food items represent a considerable share of euro-area household expenditures, while food prices have accounted for a large part of HICP volatility since the start of the euro. Since food commodities are a key input factor in the food production function, understanding the dynamics of food commodity prices is very important for monetary policymakers. In this paper, I have examined the causal effects of fluctuations in international food commodity prices on inflation in the euro-area. To address endogeneity issues, I explore the time lag between planting and harvesting of at least three months to construct a series of unanticipated global (nonEuropean) harvest shocks, which is then used as an instrument to achieve identification in an SVAR-IV model for the euro-area economy.

The effects of an exogenous shift in international food commodity prices on euro-area inflation turn out to be quite strong and economically meaningful. On average, exogenous swings in international food commodity prices have historically accounted for almost $30 \%$ of HICP volatility in the medium term. Developments in global food commodity markets should thus be closely monitored by policymakers. I document a direct pass-through along the food production chain via spillovers on EU farm-gate and internal wholesale market prices to retailer prices of food items. However, there also appear to be indirect effects since an exogenous rise in international food commodity prices triggers a depreciation of the euro, resulting in higher import prices and second-round effects due to a rise in nominal wages. Backof-the-envelope calculations reveal that the rise in nominal wages is the most important determinant of the inflationary effects.

A remarkable observation is that large and persistent autonomous swings in international food commodity prices had an important impact on inflation developments in the era after the Great Recession. Specifically, a counterfactual simulation reveals that inflation would have been between $0.2 \%$ and $0.8 \%$ lower in the period 2009 to 2012 and between $0.4 \%$ and $0.8 \%$ higher in 2014 and 2015. These two periods have often been described as the missing disinflation and missing inflation episodes, respectively, and have led economists to question and reassess the relation between real activity and inflation. The counterfactual simulation, however, suggests that both episodes might be less puzzling than previously thought and can at least partly be explained by developments in global food commodity markets.
Finally, the inflationary effects of global food market shocks have been very different across individual member states. The source of the asymmetries can again be explained by labor market dynamics. Strong second-round effects via rising wages are present in only some member states, particularly countries with formal wage indexation mechanisms. The asymmetric impact across countries creates problems for policymakers since a single monetary policy stance is acceptable only if countries experience similar inflation developments. The concerns of the Governing Council of the ECB about the existence of schemes in which nominal wages are indexed to consumer prices is therefore valid (see ECB, 2008).

Overall, the analysis in this paper stresses the importance of the global nature of inflation, a conclusion that is in line with earlier studies (Borio \& Filardo, 2007; Monacelli \& Sala, 2009; Ciccarelli \& Mojon, 2010; Mumtaz \& Surico, 2012; Eickmeier \& Pijnenburg, 2013). Nevertheless, there are still a number of issues that require additional investigation. A pertinent question is whether the pass-through of food commodity price shocks to consumer prices is nonlinear or whether there has been time variation in the transmission mechanisms. These questions are left for future research.

\section{REFERENCES}

Abbott, Philip, Christopher Hurt, and Wallace Tyner, "What's Driving Food Prices in 2011?" Farm Foundation technical report (2011).

Baker, Scott, Nicholas Bloom, and Davis Steven, "Measuring Economic Policy Uncertainty," Quarterly Journal of Economics 131 (2016), 1593-1636. 10.1093/qje/qjw024

Ball, Laurence, and Sandeep Mazumder, "Inflation Dynamics and the Great Recession," Brookings Papers on Economic Activity 42 (2011), 337 405 .

Bayoumi, Tamin, and Barry Eichengreen, "Shocking Aspects of EuroEuro Monetary Unification," NBER working paper 3949 (1992).

Blomberg, Brock, and Ethan Harris, "The Commodity-Consumer Price Connection: Fact or Fable?" FRBNY Economic Policy Review 1:3 (1995), 21-38.

Bobeica, Elena, and Marek Jarocinski, "Missing Disinflation and Missing Inflation: The Puzzles That Aren't," European Central Bank working paper series (2017).

Borio, Claudio, and Andrew Filardo, "Globalisation and Inflation: New Cross-Country Evidence on the Global Determinants of Domestic Inflation," BIS working papers (2007).

Bruggemann, Ralf, Carsten Jentsch, and Carsten Trenkler, "Inference in VARs with Conditional Heteroscedasticity of Unknown Form," Journal of Econometrics 191 (2016), 69-85. 10.1016/ j.jeconom.2015.10.004

Ciccarelli, Matteo, and Benoit Mojon, "Global Inflation," this REVIEW 92 (2010), 524-535

Ciccarelli, Matteo, and Chiara Osbat, "Low Inflation in the Euro Area: Causes and Consequences," European Central Bank occasional paper 181 (2017).

Coibion, Olivier, and Yuriy Gorodnichenko, "Is the Phillips Curve Alive and Well After All? Inflation Expectations and the Missing Disinflation," American Economic Journal: Macroeconomics 7 (2015), 97-232. $10.1257 / \mathrm{mac} .20130306$

Constancio, Vitor, "Understanding Inflation Dynamics and Monetary Policy," in Annual Economic Policy Symposium, Federal Reserve Bank of Kansas City (2015).

Conti, Antonio, Stefano Neri, and Andrea Nobili, "Low Inflation and Monetary Policy in the Euro Area," European Central Bank working paper series (2017).

Daveri, Francesco, and Guido Tabellini, "Unemployment, Growth and Taxation in Industrial Countries," Economic Policy 15 (1988), 47-104. 
De Winne, Jasmien, and Gert Peersman, "Macroeconomic Effects of Disruptions in Global Food Commodity Markets: Evidence for the United States," Brookings Papers on Economic Activity (2016), 183286.

ECB, Wage Indexation Mechanisms in Euro Area Countries," Monthly Bulletin (2008), 51-52.

"Recent Developments in Global and Euro Area Trade," Monthly Bulletin (2010), 93-107.

Eickmeier, Sandra, and Katharina Pijnenburg, "The Global Dimension of Inflation: Evidence from Factor-Augmented Phillips Curves," Oxford Bulletin of Economics and Statistics 75 (2013), 103-122. 10.1111/obes. 12004

Enders, Walter, and Mathew Holt, "The Evolving Relationships between Agricultural and Energy Commodity Prices: A Shifting-Mean Vector Autoregressive Analysis" (pp. 135-187), in J. Chavas, D. Hummels, and B. Wright, eds., The Economics of Food Price Volatility (Chicago: University of Chicago Press, 2014).

Ferrucci, Gianluigi, Rebeca Jimenez-Rodriguez, and Luca Onorante, "Food Price Pass-Through in the Euro Area: Non-Linearities and the Role of the Common Agricultural Policy," International Journal of Central Banking 8 (2012), 179-217.

Friedrich, Christian, "Global Inflation Dynamics in the Post-Crisis Period: What Explains the Puzzles?" Economics Letters 142 (2016), 31-34. 10.1016/j.econlet.2016.02.032

Furceri, Davide, Prakash Loungani, John Simon, and Susan Wachter, "Global Food Prices and Domestic Inflation: Some Cross-Country Evidence," IMF working paper 133 (2015).

Furlong, Fred, and Robert Ingenito, "Commodity Prices and Inflation," Economic Review-Federal Reserve Bank of San Francisco 2 (1996).

Gordon, Robert, "The Phillips Curve Is Alive and Well: Inflation and the NAIRU during the Slow Recovery," NBER working paper 19390 (2013).

Jentsch, Carsten, and Carsten Lunsford, “The Dynamic Effects of Personal and Corporate Income Tax Changes in the United States: Comment," American Economic Review 109 (2019), 2655-2678. 10.1257/aer.20162011

Kanzig, Diego, "The Macroeconomic Effects of Oil Supply News: Evidence from OPEC Announcements," London Business School working paper (2018).

Larsson, Nina, "Inflation Expectations," Norges Bank mimeograph (2015).

Mertens, Karel, and Morten Ravn, "The Dynamic Effects of Personal and Corporate Income Tax Changes in the United States," American Economic Review 103 (2013), 1212-1247. 10.1257/aer.103.4.1212 "The Dynamic Effects of Personal and Corporate Income Tax Changes in the United States: Reply," American Economic Review 109 (2019), 2679-2691. 10.1257/aer.20180707

Messina, Julian, and Anna Sanz-de Galdeano, "Wage Rigidity and Disinflation in Emerging Countries," American Economic Journal: Macroeconomics 6 (2014), 102-133. 10.1257/mac.6.1.102
Monacelli, Tommaso, and Luca Sala, "The International Dimension of Inflation: Evidence from Disaggregated Consumer Price Data," Journal of Money, Credit and Banking 41 (2009), 101-120. 10.1111/ j.1538-4616.2008.00200.x

Montiel Olea, Jose Luis, James Stock, and Mark Watson, "Inference in Structural VARs with External Instruments," mimeograph (2016).

Mumtaz, Haroon, and Paolo Surico, "Evolving International Inflation Dynamics: World and Country-Specific Factors," Journal of the European Economic Association 10 (2012), 716-734. 10.1111/ j.1542-4774.2012.01068.x

Murphy, Robert, and Adam Rohde, "Rational Bias in Inflation Expectations," Eastern Economic Journal 44 (2018), 153-171. 10.1057/ eej. 2015.50

OECD. 2013 Edition of the OECD Employment Outlook (Paris: OECD Publishing, 2013).

Pedersen, Michael, "Propagation of Shocks to Food and Energy Prices: An International Comparison," Central Bank of Chile working papers 648 (2011).

Peersman, Gert, Sebastian Rüth, and Wouter Van der Veken, "The Interplay between Oil and Food Commodity Prices: Has It Changed over Time?" CESifo working paper 7826 (2019).

Peersman, Gert, and Ine Van Robays, "Oil and the Euro Area Economy," Economic Policy 24 (2009), 603-651. 10.1111/ j.1468-0327.2009.00233.x

Roberts, Michael, and Wolfram Schlenker, "Identifying Supply and Demand Elasticities of Agricultural Commodities: Implications for the US Ethanol Mandate,” American Economic Review 103 (2013), 2265-2295. 10.1257/aer.103.6.2265

Sims, Christopher, James Stock, and Mark Watson, "Inference in Linear Time Series Models with Some Unit Roots," Econometric 58 (1990), 113-144. 10.2307/2938337

Smets, Frank, and Raf Wouters, "Shocks and Frictions in US Business Cycles: A Bayesian DSGE Approach," American Economic Review 97 (2007), 586-606. 10.1257/aer.97.3.586

Sockin, Michael, and Wei Xiong, "Informational Frictions and Commodity Markets," Journal of Finance 70 (2015), 2063-2098. 10.1111/ jofi. 12261

Stock, James, and Mark Watson, "Disentangling the Channels of the 20072009 Recession," Brookings Papers on Economic Activity (2012), 81-156.

Trehan, Bharat, "Household Inflation Expectations and the Price of Oil: It's Deja Vu All Over Again," FRBSF Economic Letter (2011).

Vavra, Pavel, and Barry Goodwin, "Analysis of Price Transmission along the Food Chain," OECD Food, Agriculture and Fisheries working papers 3 (2005). 